UDC 621.316

DOI: https://doi.org/10.32840/1814-1161/2020-5-2

\author{
Marekha Iryna \\ Candidate of Economic Sciences, \\ Sumy State University \\ Makarenko Tetiana \\ Master Student, \\ Sumy State University
}

Mapexa I.C.

кандидат економічних наук,

Сумський державний університет

Макаренко T.Ю. магістр,

Сумський державний університет

\title{
EUROPEAN SMART ENERGY MARKET ${ }^{1}$
}

\section{ЄВРОПЕЙСЬКИЙ РИНОК РОЗУМНОЇ ЕНЕРГЕТИКИ}

In the article, the authors revealed that the European energy market has been fundamentally transformed towards the implementation of smart grid technologies. Moreover, the authors discovered that smart energy technologies have a ubiquitous application on the European energy market which is a case for the single energy strategy. It has been outlined that the main benefits of smart grids technologies realization are the increased quality and reliability of power supply that ensure energy security on the European market. The article specifically focuses on two segments of the European smart energy market, namely on smart grids and smart metering devices which constitute the core of intellectually-based market model. The authors explored and analyzed the existing smart metering market model related to the European countries. The article in addition includes the economic estimation of top growth segments of the European smart energy market. The authors presented a statistical evidence for estimation of future smart energy market trends.

Keywords: energy market, energy system, economic benefits, smart grids, smart metering, European countries.

У статті зосереджено увагу на тому, що в європейських країнах вже тривалий час відбувається процес модернізації енергетичного ринку у напрямку розбудови розумних мереж, що отримали назву smart grid. Поняття smart grid включає в себе призначений для передачі енергії від виробника до споживача численний комплекс технологічних процесів, сучасних інформаційних та комунікаційних технологій, інноваційного обладнання та додатків, що взаємодіють один з одним і утворюють єдину інтелектуальну систему енергопостачання. Передбачається, що технологічна платфрорма smart grid дозволяє здійснювати інтелектуальну обробку усього масиву даних, що надходять від усіх компонентів мереж, і на основі даної інформації- оптимізувати використання енергії, підвищувати надійність та ефективність енергетичної системи. Авторами встановлено, що концепція smart grid також розглядається в Європі на різних рівнях управління енергетичною інфраструктурою як ідеологічна основа рефрормування енергетики. З'ясовано, що в європейській практиці розбудови розумних мереж чітко простежується орієнтація на клієнта, що дозволяє говорити про домінування ринку покупия. Такий підхід передбачає, перш за все, спрощення підключення до системи нових абонентів, а також гнучкість мережі, яка дозволяє підлаштуватися під запити споживачів, економічність та екологічність. Аналіз європейського ринку розумної енергетики дозволяє констатувати, що ключовими аспектами його розвитку є забезпечення високих показників надійності, безпеки та економічної доцільності на основі сучасних технологій моніторингу, управління, зв'язку ат інформування. Європейська інтелектуальна енергетична модель представляє собою систему нового покоління. Головна мета такої ринкової моделі - забезпечення ефективного використання доступних ресурсів для надійного та якісного обслуговування клієнтів. Відзначено, що основою європейського енергетичного ринку є сучасні технологічні засоби і побудова єдиної інтелектуальної ієрархічної системи управління, що забезпечує високу поточну та футуристичну ємність енергетичного ринку на європейському континенті.

Ключові слова: енергетичний ринок, енергетична система, економічні вигоди, розумні мережі, розумні лічильники, європейські країни.

${ }^{1}$ This work was supported by the Ministry of Education and Science of Ukraine (Project No. 0119 U100766 «The optimization model of smart and secure energy grids building: an innovative technologies of enterprises and regions ecologisation»). 
В статье авторами установлено, что европейский энергетический рынок был кардинально трансформирован в направлении внедрения технологий smart grid. Более того, авторы выявили всеобщий характер применения smart-технологий на европейском энергетическом рынке, что свидетельствует о единой энергетической стратегии. Были очерчены основные преимущества реализации технологий smart grid, среди которых отмечены улучшение качества и надежность поставки энергии, обеспечивающие энергетическую безопасность на европейском рынке. В статье основной акцент сделан на двух сегментах европейского рынка smart-технологий, а именно умных сетей и умных учетных систем, что составляют ядро интеллектуально-центрической модели энергетического рынка. Авторы исследовали и проанализировали существующие рыночные модели умных учетных систем по отношению к европейским странам. В дополнение в статье приведена экономическая оценка ключевых растущих сегментов на рынке умной энергии в Европе. Авторами представлена статистическая оценка будущих тенденций развития рынка умной энергии.

Ключевые слова: энергетический рынок, энергетическая система, экономические выгоды, умные сети, умные учетные системы, европейские страны.

Problem statement. The intensive use of information technologies in power systems in the European countries has led to the creation of a concept called the smart energy. Among the advantages of this concept we can mention optimal network control, the most favorable use of equipment, increased quality and reliability of power supply, facilitation of the integration of renewable energy sources, optimal planning of the transmission and distribution systems, the development of the use of distributed generation and reduced system's costs [1]. The ubiquitous exploitation of smart energy technologies resulted in emergence of smart energy markets. These markets have fundamentally transformed the European energy sector in terms of installation of smart grids and smart metering devices. These innovative technologies require new market approach and market regulations. In this relation, there is a crucial need to explore emerging smart energy markets, their structure, functions and key players. Evidently, this raises new questions about energy markets and market background of technologicallyoriented energy advancements.

Recent research analysis. Smart energy markets are the subject to the academic scrutiny. In the paper [2] the author debates that smart grids markets open a wide range of opportunities for transforming the old unsustainable energy supply complex into a new more sustainable socio-technical system involving much more actors. The role of implementation of smart grid approach into the renewable energy sector was actively discussed in the research [3]. The need of implementation of smart technologies and their overall effects for the electrical infrastructure was outlined in the paper [4] and [5]. The importance of creating energy hubs based on smart energy concept was declared in the paper [6]. The necessity to use smart grids and meters aimed at energy markets decentralization in the European Union was stressed in the paper [7]. Key findings and future trends for the European smart grid market were presented in [8]. The scholars' results mentioned above contributed significantly to the exploration of smart energy markets on the global level and European one in particular. In this paper, we propose to concentrate primarily on the unique smart energy market of the European countries. The main attention will be paid to the structure, analysis and statistical grounding of the European smart energy market.

Objective statement. The main task of the article is to conduct analytical review of the European smart energy market in terms of deep analysis of existing models, current projects, key market segments, up-todate technologies and ongoing initiatives.

Research results. Structurally, the European smart energy market is represented by the following key segments: smart grids market and smart metering market (gas and electricity markets). Smart grids are the network of transmission lines, substations, transformers and more that deliver electricity from the power plant to customers' homes or businesses. Smart meters are the way for businesses and households to not only keep track of how much energy they have used, but to collect data to make indepth analyses and control of usage. The European Union is an active implementer of smart energy initiatives. It has designed a common step-by-step strategy. Implementing smart grids requires 10 steps to be taken, many of which are closely interrelated and will develop simultaneously rather than in isolation (Table 1).

Smart grids require smart components. In order to pave the way towards flexible European grids by 2020, we need clarity on the desired functionalities and services of smart grids and their possible implications for the power system. In paper [9], the authors suggest the following categorization of smart grids concept for the European Union (see Figure 1).

The advantages of the smart metering implementation for the EU market [10]:

1. Prove to be the tool to entice consumers to manage their consumption better and reduce usage leading the way to improved service levels through richer billing information.

2. Be a key weapon in the fight on climate change.

3. Help governments implement liberalization of energy markets.

4. Allow the full realization of the Energy Services Directive.

The analysis of smart metering market is conducted in the Table 2.

The European market of smart metering technologies demonstrates a steady tendency to growth. Evidence from the United Kingdom smart energy market is an obvious case (Figure $2-3$ ).

The number of domestic smart meters installed in the United Kingdom during 2012-2018 is depicted in the Figure 2.

The number of non-domestic smart meters installed in the United Kingdom during 2012-2018 is depicted in the Figure 3.

The following European Union countries are the leaders in implementation of smart energy solutions: 
1. Smart metering projects - Italy, Finland, France, the Netherlands, Malta.

2. Integrated systems - Germany, Spain, Austria, Belgium, Portugal, Norway.

Top growth segments within smart energy markets in Europe are estimated in the Table 3.

The European smart energy market can be described by the following expected numbers [8]:

1. European smart grid market revenue is expected to grow at a CAGR of $8,6 \%$ to 2025 .

2. Demand response will be the fastest growing segment within the European smart grid market with a 10 year growth rate at $17,6 \%$.

3. European smart meter rollout is going slower than expected. The market will peak in 2021. France, the United Kingdom, Germany, and Italy will be the key countries with bulk smart meter shipment in 2025.

4. Distribution automation, which is a subset of distribution grid management, has strong growth opportunities with revenue growing at CAGR of $8,2 \%$ to 2025. Europe is the biggest distribution automation market globally and is expected to maintain its leadership position even in 2025.

5. Projects of common interest and the European Council target for $10 \%$ interconnection by the end of 2020 will drive growth of HVDC (high-voltage direct current) and FACTS (flexible alternating current transmission systems).

Key trends in development of the European energy market from a future perspective are shown in the Figure 4.

The estimates of the smart energy markets of the European counties show their high performance and tremendous perspective potential.

Conclusions. The highly intensive development and huge demand for smart grids in the European countries require a transition towards the new paradigm of energy market. This transition should be supported by the creation of intellectually-based model of energy market. An important part of this becomes an emergence of smart markets and smart consumers. The European smart energy market can be described

Table 1

Strategy for implementation of Smart Grids at the European Union market [9]

\begin{tabular}{|c|c|c|c|c|c|c|c|c|c|c|c|c|}
\hline & Step & 2011 & 2012 & 2013 & 2014 & 2015 & 2016 & 2017 & 2018 & 2019 & 2020 & 2021 \\
\hline \multirow{2}{*}{$\begin{array}{l}\text { Commer- } \\
\text { cialization in } \\
\text { the Member } \\
\text { States }\end{array}$} & 10 & & & & & \multicolumn{7}{|c|}{ Moving to real customer participation in the power market } \\
\hline & 9 & & & & & \multicolumn{7}{|c|}{ Integrating large-scale e-mobility, heating, cooling and storage } \\
\hline \multirow{4}{*}{$\begin{array}{l}\text { Deployment } \\
\text { in the Member } \\
\text { States }\end{array}$} & 8 & & & & & \multicolumn{7}{|c|}{ Aggregating distributed energy sources } \\
\hline & 7 & & & & & \multicolumn{7}{|c|}{ Moving to integrated local \& central balancing of all generation } \\
\hline & 6 & & \multicolumn{9}{|c|}{ Monitoring and controlling the grid \& distributed generation } & \\
\hline & 5 & & \multicolumn{9}{|c|}{ Rolling out smart metering - informed customers } & \\
\hline \multirow{4}{*}{$\begin{array}{l}\text { Facilitation - } \\
\text { both national } \\
\text { and EU level }\end{array}$} & 4 & \multicolumn{8}{|c|}{ Testing through demonstration projects \& sharing knowledge } & & & \\
\hline & 3 & \multicolumn{5}{|c|}{\begin{tabular}{|l|l|} 
Setting standards and ensuring \\
data protection \& privacy
\end{tabular}} & & & & & & \\
\hline & 2 & \multicolumn{10}{|c|}{ Developing market models } & \\
\hline & 1 & \multicolumn{10}{|c|}{ Providing regulatory incentives for innovative grid investments } & \\
\hline
\end{tabular}

SMART NETWORK MANAGEMENT:

$\checkmark$ Conventional grid development combined with...

$\checkmark$ Faster fault identification and self-healing capabilities via grid automation

$\checkmark$ Advanced network operation and control
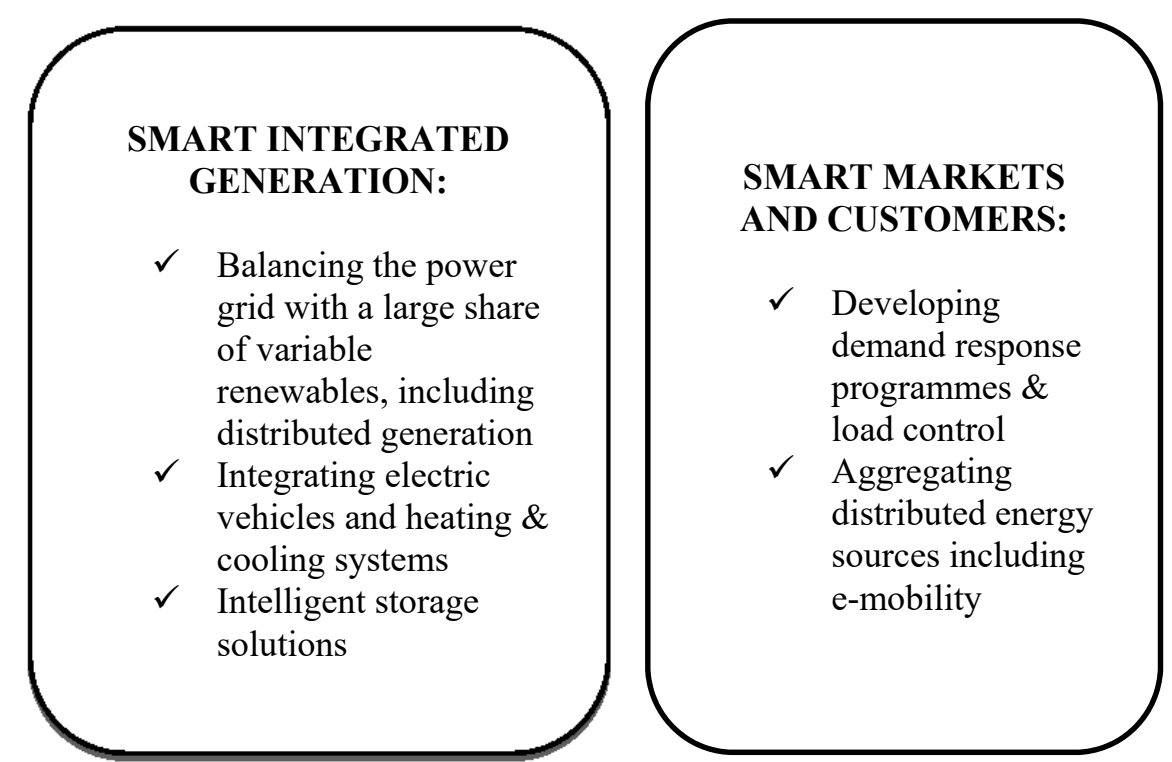

SMART MARKETS

$\checkmark$ Developing demand response programmes \& control sources including e-mobility

Figure 1. Organizational model of Smart Grids for the EU [9] 
The European smart metering market model [10]

\begin{tabular}{|l|l|}
\hline \multicolumn{1}{|c|}{ Components } & \multicolumn{1}{c|}{ Description } \\
\hline Smart grids & $\begin{array}{l}\text { Smart meters are the cornerstones of smart grids. They give accurate insight in the quality of } \\
\text { power supply and any disturbances in electricity networks. Fraud and leakages can be detected } \\
\text { easily, so the cost of economical energy losses decreases. They support the European efforts } \\
\text { for efficient use of energy and getting climate changes under control. }\end{array}$ \\
\hline Consumers/Prosumers & $\begin{array}{l}\text { Provide more and better information on their energy consumption and generation (real-time } \\
\text { feedback, correct billing, on-line data); dynamic tariffs, such as TimeofUse; demand response } \\
\text { programmes; easy supplier switching; an increasing number of consumers are becoming energy } \\
\text { producers (selling energy generated locally). }\end{array}$ \\
\hline Smart homes & $\begin{array}{l}\text { Provide an interface for smart homes devices; allow for comprehensive home energy } \\
\text { management; enable buildings communications systems with knock on effects for controlling } \\
\text { heating, lighting, ventilation and appliance use. }\end{array}$ \\
\hline $\begin{array}{l}\text { Renewables and } \\
\text { distributed generation }\end{array}$ & $\begin{array}{l}\text { Better integrate the growing number of embedded renewable generators, such as wind and } \\
\text { photovoltaic; measure exported power when the customers use less power than they generate; } \\
\text { measure the output of the generator and supply this data to the energy company (complete } \\
\text { picture of the generator's performance); manage fleets of embedded generators as though they } \\
\text { were a single large plant - so-called virtual power plants. }\end{array}$ \\
\hline Electric vehicles & $\begin{array}{l}\text { Efficiently managed when charged or used as a power storage and source; information on how } \\
\text { and when to charge or give energy back to the network independently of the location or time. }\end{array}$ \\
\hline
\end{tabular}

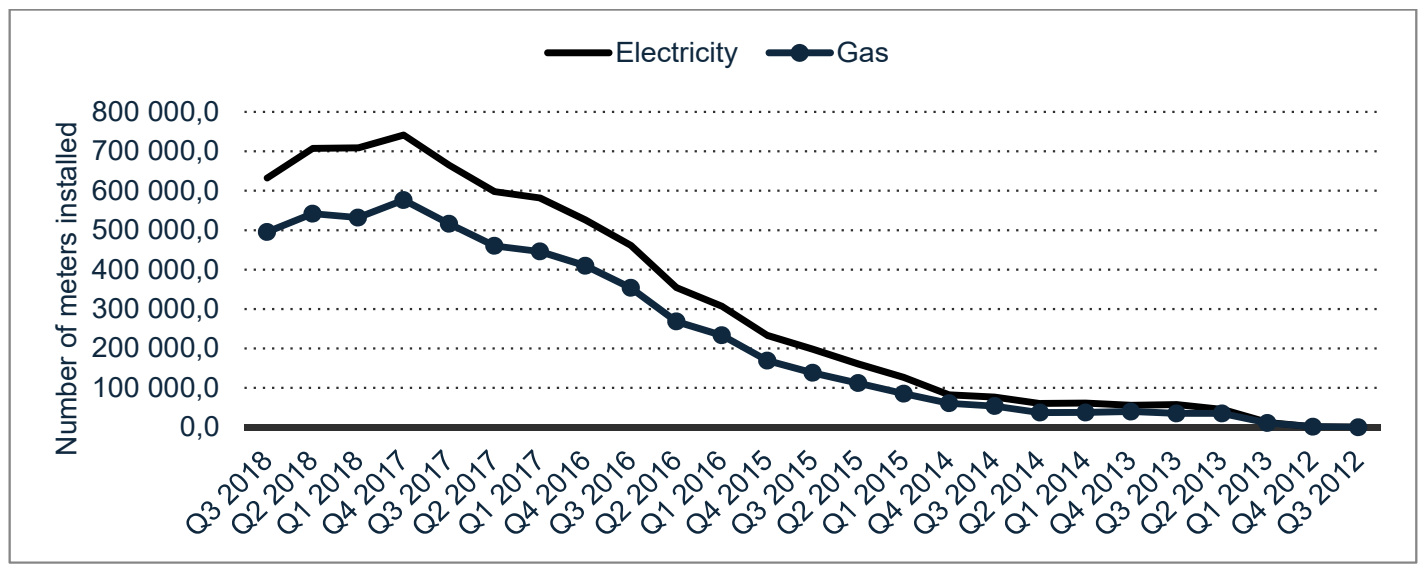

Figure 2. Smart metering market for domestic users in the UK [11]

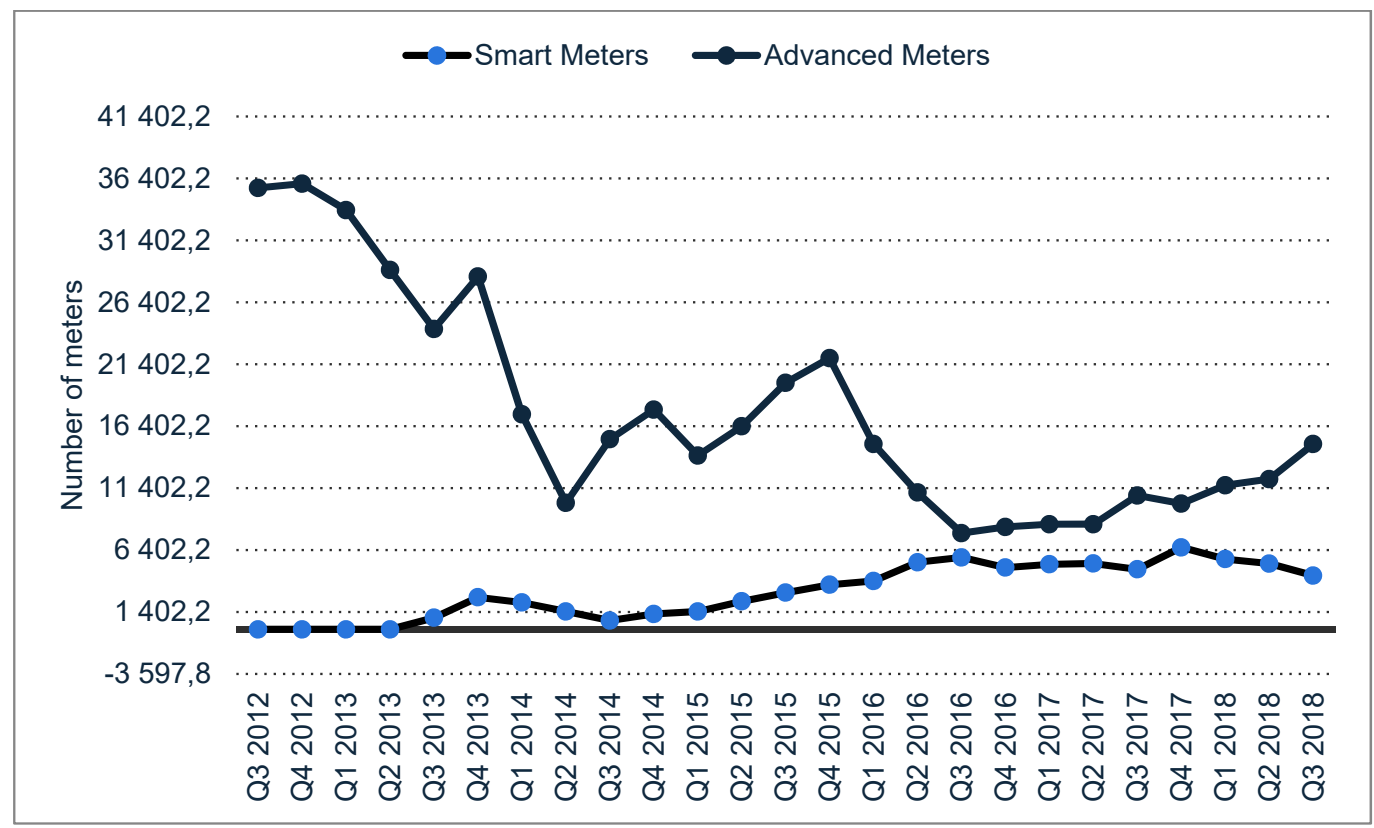

Figure 3. Smart metering market for non-domestic users in the UK [11] 
Top growth segments of the European smart energy market [8]

Table 3

\begin{tabular}{|l|l|}
\hline \multicolumn{1}{|c|}{ Areas } & \multicolumn{1}{c|}{ Estimation } \\
\hline $\begin{array}{l}\text { Advanced Metering } \\
\text { Infrastructure (AMI) }\end{array}$ & $\begin{array}{l}\text { AMI revenue is likely to grow at a CAGR of 12,4 \% till 2025. The revenue will witness very high } \\
\text { growth of 31\% till the end of 2020 due to massive rollouts in the United Kingdom and France. In } \\
\text { fact, France is expected to surpass Spain to become the largest smart meter market in Europe. }\end{array}$ \\
\hline $\begin{array}{l}\text { Demand Response } \\
\text { (DR) }\end{array}$ & $\begin{array}{l}\text { France, Switzerland, the United Kingdom, Sweden, and Belgium offer good growth opportunities } \\
\text { for demand response. The National Grid in the United Kingdom has tied up with various } \\
\text { aggregators to implement DR programs and recently tendered for 200 MW of fast frequency } \\
\text { response. EDF in France offers load management to its customers and is now in the process of } \\
\text { setting up third-party aggregators to facilitate load curtailment during peak periods. }\end{array}$ \\
\hline $\begin{array}{l}\text { Smart Network } \\
\text { Management }\end{array}$ & $\begin{array}{l}\text { The European substation and distribution automation market was worth close to 3,1 billion in } \\
\text { 2015, and is expected to grow at around 8 \% CAGR till the end of 2020. New technological } \\
\text { trends include intelligent equipment that are able to perform remote monitoring and ere based } \\
\text { on wireless sensor networks (WSNs). }\end{array}$ \\
\hline $\begin{array}{l}\text { Advanced transmission } \\
\text { technologies (ATT) }\end{array}$ & $\begin{array}{l}\text { Cross border integration of electricity markets and growth of large scale renewable energy } \\
\text { sources (RES) are driving the growth of advanced transmission technologies. Revenue from } \\
\text { HVDC and FACTS accounted for \$ 2,0 billion in 2015 and is expected to reach \$ 2,8 billion at } \\
\text { the end of 2020. Wireless power transmission is a ground-breaking technology which is still in } \\
\text { the demonstration phase and if successful, could revolutionize the transmission of electricity. }\end{array}$ \\
\hline
\end{tabular}

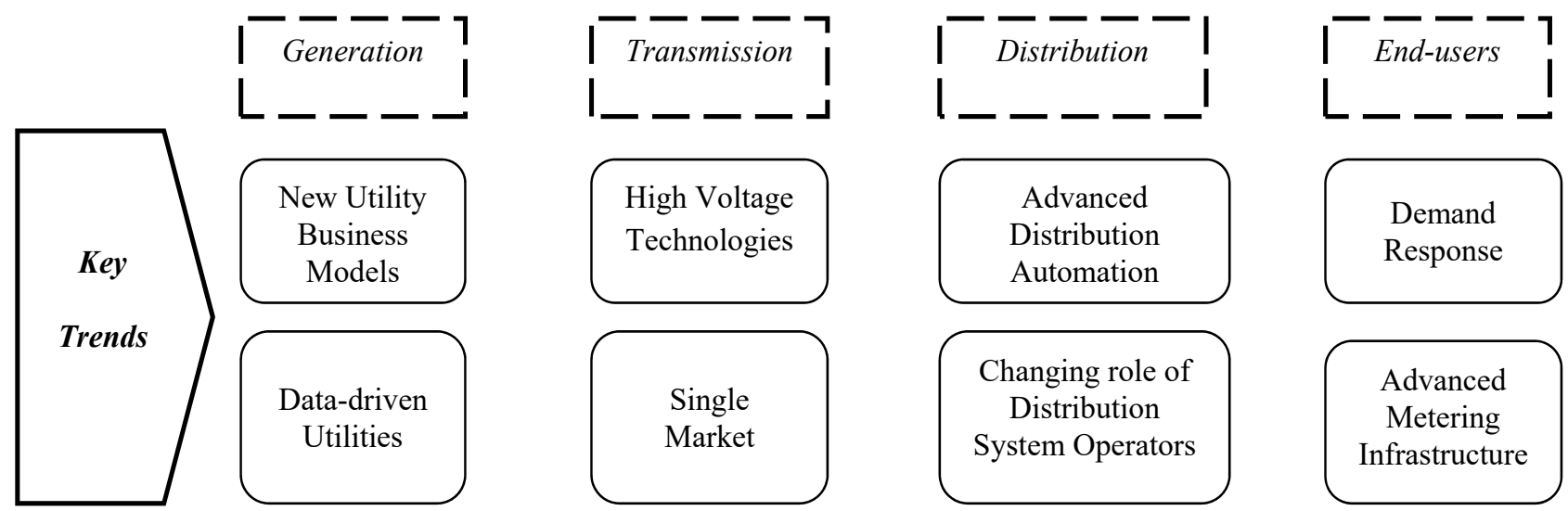

Figure 4. Future trends for the European smart energy market [8]

as a fully integrated system. Moreover, decentralization and liberalization of energy market determine its huge capacity and perspective growth. The investigation of efficiency of smart energy solutions for specific European countries is a subject for further research.

\section{References:}

1. Mohammadi M., Noorollahi Y., Mohammadi-Ivatloo B., Yousefi H. (2017) Energy Hub: From A Model To A Concept - A Review. Renewable and Sustainable Energy Reviews, no. 80, pp. 1512-1527.

2. Schleicher-Tappeser R. (2012) The Smart Grids Debate in Europe. SEFEP Working Paper. Available at: https://sustainablestrategies.eu/wp-content/uploads/2018/ 05/ SEFEP -SmartGrids_EU.pdf (accessed 01 October 2020)

3. Hossain M., Madlool N., Rahim N., Selvaraj J., Pandey A., Khan A.F. (2016) Role of Smart Grid in Renewable Energy: An Overview. Renewable and Sustainable Energy Reviews, no. 60, pp. 1168-1184.

4. Güngör V.C., Sahin D., Kocak T., Ergüt S., Buccella C., Cecati C., Hancke G.P. (2011) Smart Grid Technologies: Communication Technologies and Standards. IEEE Transactions on Industrial Informatics, no. 7 (4), pp. 529-539.
5. Tuballa M.L., Abundo M.L. (2016) A Review Of The Development Of Smart Grid Technologies. Renewable and Sustainable Energy Reviews, no. 59, pp. 710-725.

6. Geidl M., Koeppel G., Favre-Perrod P., Klockl B., Andersson G., Frohlich K. (2007) Energy Hubs For The Future. IEEE Power and Energy Magazine, no. 5, pp. 24-30.

7. Leal-Arcas R., Akondo N., Rios J.A. Energy Decentralization in the European Union. URL: https://www.researchgate.net/ publication/331098073_Energy_decentralization in the European_Union_Energy_decentralization_in_the_EU_Energy decentralization in the_European_Union (accessed 28 September 2020).

8. Tohani M. Frost \& Sullivan European Smart Grid Market Overview. Available at: https://ww2.frost.com/ files/2314/7151/3698/European_Smart_grid_market.pdf (accessed 04.10.2020).

9. EURELECTRIC (2010). 10 Steps to Smart Grids. Available at: https://www3.eurelectric.org/media/26140/broch. 10steps_Ir-2011-030-0304-01-e.pd (accessed 29 August 2020).

10. Official website of ESMIG. Available at: https://esmig.eu/ page/smart-metering-technologies (accessed 02 September 2020).

11. Official website of STATISTA. Available at: https://www.statista.com/ (accessed 15 March 2020). 